\title{
Retraction of Effects of Digital Flipped Classroom Teaching Method Integrated Cooperative Learning Model on Learning Motivation and Outcome
}

Jian Qiang *

Issue Date: 26 December 2018

Original Article: Effects of Digital Flipped Classroom Teaching Method Integrated Cooperative Learning Model on Learning Motivation and Outcome

EURASIA J. Math., Sci Tech. Ed (2018), 14(6), 2213-2220.

https:// doi.org/10.29333/ejmste/86130

This document states that the Article is retracted by request from the author.

http://www.ejmste.com

(C) 2019 by the authors; licensee Modestum Ltd., UK. This article is an open access article distributed under the terms and conditions of the Creative Commons Attribution License (http://creativecommons.org/licenses/by/4.0/). \xcjianqiang@163.com (*Correspondence) 